\title{
Performance Improvement of Roller Burnishing Process- A Review
}

\author{
Priyanka S. Yadav ${ }^{1}$, Dayanand A. Ghatge ${ }^{2}$ \\ Dept of Mechanical Engineering, Karmaveer Bhaurao Patil College of Engineering, Satara, Maharashtra, India ${ }^{1,2}$
}

\begin{abstract}
This paper presents a review on performance improvement of roller burnishing process. Roller burnishing is a surface finishing process which is economical as compared to other surface finishing process. Roller burnishing along with good quality surface finish also gives improved surface properties. The process parameters mostly considered are burnishing speed, feed rate, number of passes and depth of penetration. Roller burnishing does not require any special arrangement for the process and can be easily carried out on a conventional lathe machine also.
\end{abstract}

Keywords: Burnishing, depth of penetration, feed rate, speed, surface hardness, surface roughness.

\section{INTRODUCTION}

Machining is the process of material removal in order to get the component into desired shape and size. The properties of machined components have gained a large importance. The properties such as surface finish, surface hardness, wear resistance, corrosion resistance, etc are to be considered. The surface finishing operations such as honing, lapping, grinding, etc can be replaced by burnishing process as the other processes exert tensile force on the component which reduces life of component due to fatigue, tension, etc. Thus, compressive stresses are found beneficial over tensile stresses on component surface. Compressive stresses can also be produced by processes other than burnishing which are shot peening, laser shock peening, etc. But these stresses were found to be relaxed when exposed to heat. This thermal relaxation of compressive stresses shortens the component life and reduces its performance. So burnishing came up as a process that could impart compressive stresses that remain unaffected also in thermal variations.

\section{BURNISHING PROCESS}

Burnishing could be a surface finishing method that involves no chip formation. In conjunction with giving finer surface finish it additionally enhances surface properties like hardness, wear resistance, fatigue life, corrosion resistance, etc. Roller Burnishing will facilitate users eliminate secondary operations for substantial time and price savings, whereas at an equivalent time rising the standard of their product. Roller burnishing could be a technique of manufacturing associate degree accurately sized, finely finished and densely compacted surface that resists wear. Hardened and extremely smooth steel rollers are brought into pressure contact with a softer work piece, as shown in figure 1 . As the pressure increases beyond the yield point of the work piece material, the surface is plastically unshaped by cold-flowing of submerged material.

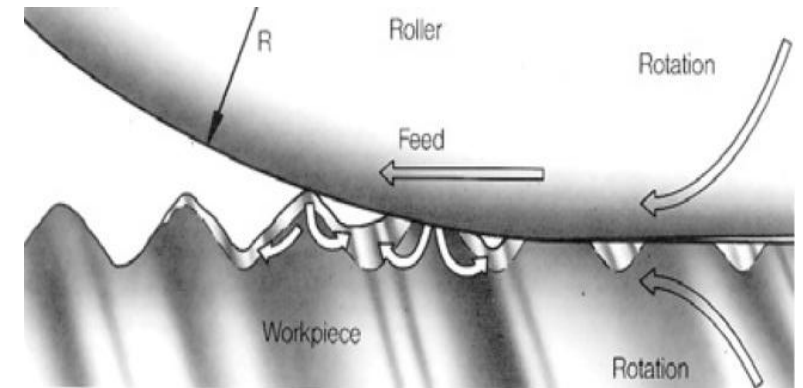

Fig. 1 Roller burnishing process [14]

\section{ADVANTAGES OF ROLLER BURNISHING}

- Roller burnishing is a quicker, cleaner, a lot of effective and a lot economical methodology of sizing and finishing elements to required specifications.

- Fantastic mirror like surface.

- Consistent dimensional tolerance and repeatability.

- Single pass operation offers terribly less cycle time.

- Will increase the surface hardness of parts.

- Reduces reworks and rejections. [15]

\section{APPLICATIONS}

Roller burnishing has long been used on a large type of automotive and significant instrumentation parts (construction, agricultural, mining so on) as well as piston and rod bores, brake system parts, transmission elements and converter bulbs. Burnishing tools are also widely applied in non-automotive applications for a range of benefits; to give higher and longer lasting seal surfaces; to enhance wear life; to cut back friction and noise levels in running parts and to boost cosmetic look. Examples embody valves, pistons of hydraulic or gas cylinders, field and garden instrumentation parts, shafts for pumps, shafts running in bushings, bearing bores, and plumbing fixtures. [15] 
IARJSET

International Advanced Research Journal in Science, Engineering and Technology

National Conference on Design, Manufacturing, Energy \& Thermal Engineering (NCDMETE-2017)

AGTI's Dr. Daulatrao Aher College Engineering, Vidyanagar Extension, Karad

Vol. 4, Special Issue 1, January 2017

\section{LITERATURE REVIEW}

1) Kiran A Patel, Pragnesh K Brahmbhatt (2016) compared the surface roughness predictions models of RSM and ANN. The comparison apparently indicates that the prediction capabilities of ANN models are much better as compared to the RSM models. A decent correlation between the expected and experimental results evolving from the model was exhibited. Thus, using the projected procedure, the optimum roller burnishing conditions ought to be obtained to regulate the surface responses of different materials. [1]

2) Ashish Deshmukh, Prof. Dr. R. N. Patil (2015) experimented on $\mathrm{Al} 6061$ to analyse the impact of burnishing process parameters on surface small hardness and therefore the effects found were as follows:

- Depth of penetration: As depth of penetration goes on increasing, the surface micro hardness improves.

- Feed: At first, at low feed micro hardness value is smaller, then once feed is raised there's increase in micro hardness up to optimum level, then there's drop in surface micro hardness value.

- Number of passes: As the number of passes increased micro hardness value conjointly increased, however at same time as speed is raised, micro hardness value drops down.

- Speed: It had been determined that there's no pattern to be followed in speed against micro hardness value.[2]

3) Mr. N. M. Qureshi et. al. (2015) took EN8 as work material to analyse the effect of burnishing on it. It was observed that up to an optimal value the increase in speed, feed and depth of penetration results in decrease in surface roughness but after that surface roughness increases.[3]

4) Mr.Ashwin Joshi, Dr.R.N.Patil (2015) experimented on Al 6061 to analyse the effect of burnishing process parameters on surface roughness and the effects found were as follows:

- Depth of penetration: As DOP increases surface roughness improves.

- Feed: As Feed increases, surface roughness reaches to high value, further increase in feed it reaches to lower surface roughness, further it reaches to higher value.

- Number of passes: As no. of passes increases, surface roughness increases to high value and further increase in speed roughness reaches to its lowest.

- Speed: As Speed increases, small change in surface roughness value and further increase in speed surface roughness decreases to lowest. [4]

5) Sundararajan.P.N, Nagarajan.N (2015) studied the effect of speed variation of internal roller burnishing process on EN8 material. It was observed that there was an increase in percentage improvement of surface finish along with an increase in speed. Optimum surface finish and surface roughness was at 2700rpm. If the speed is different than optimum value, the improvement in surface finish and surface roughness is less. [5]

6) Jayakrishnan J, Suraj R. (2014) experimented on $\mathrm{HCHCr}$ tool steel. The results found were as follows:

- Burnishing force: As force is increased, surface roughness is decreased and correspondingly surface hardness is increased.

- Burnishing speed: As speed is increased the area of contact between the tool and the work piece reduces. This results in a scenario within which the amount of deformation reduces resulting into increase in surface roughness and decrease in micro hardness.

- Burnishing feed: As feed is increased, contact between the tool and the work piece surface is reduced resulting in increase of surface roughness as no deformation takes place. In the meantime, the micro hardness keeps reducing as the feed goes on increasing.

- Number of passes: With increase in number of passes, surface roughness decreases while hardness increases.[6]

7) Tao Zhang, Nilo Bugtai, Ioan D. Marinescu (2014) carried out experiments on 17-4 PH stainless steel. The results found were higher pressure leads to rougher surfaces. While the feed slightly decreases the surface roughness from low to middle level, the further increase of feed will increase the surface roughness.[7]

8) Anish P. Borkar, Prasad S. Kamble and Chandrakant Y. Seemikeri (2014) used INCONEL 718 as study material and the effect was found to be as follows:

- Speed: As speed increases, surface roughness decreases while micro hardness increases.

- Feed: As feed rate increases, surface roughness decreases after a considerable increase and micro hardness also increases.

- No. of passes: With increase in no of passes, surface roughness as well as micro hardness decreases.[8]

9) Shashi Prakash Dwivedi, Satpal Sharma, Raghvendra Kumar Mishra (2014) studied the effect of burnishing process parameters on $\mathrm{A} 356 / 5 \% \mathrm{SiC}$ composite.

- Burnishing speed: surface roughness decreases with the increase in burnishing speed.

- Burnishing force: By increasing the burnishing force, the surface roughness is increased.

- Number of passes: With an increase in number of passes, the surface roughness increases.[9]

10) Jignesh R. Patel, Prof. S. M. Patel (2014) experimented on $\mathrm{C} 20$ carbon steel. The results were:

- Burnishing speed: When speed is low, S.R is low and $\mathrm{S} . \mathrm{H}$ is high and then increase in speed causes both to decrease and after that increase in speed causes low S.R. 
- Burnishing force: On high force in both parameter S.R • decrease and S.H increase and low force S.R is increase and S.H as decrease.

- Burnishing feed: Increase of feed in both parameter S.R increase and S.H decrease. [10]

11) Dinesh Kumar, Alok Kumar (2014) concentrated on effect of interference while burnishing of mild steel specimen. They determined that as interference increases finish obtained increases. It becomes maximum at a particular interference value and then decreases. While surface hardness also increases with interference increases.[11]

12) K Saraswathamma, G Venkateswarlu, S Venkatarami Reddy (2014) used 6063 aluminium alloy as experimental work piece. The results found were as follows:

- By the increase of interference surface roughness decreases due to increase of burnishing force.

- By the increase of speed, surface roughness increases up to optimum level and then decreases.

- Due to increase in feed, surface roughness increases.[12]

13) P. S. Kamble, V. S. Jadhav (2012) experimented on plain carrier of planetary type gear box (EN8). The internal roller burnishing gave results as follows:

- As feed increases, roughness as well as hardness decreases.

- As speed increases than optimum value, roughness starts increasing \& micro hardness increases as speed increases.

- As number of passes increases, roughness start increasing \& micro hardness decreases.[13]

14) J.N. Malleswara Rao, Dr. A. Chenna Kesava Reddy, Dr. P. V. Rama Rao (2011) studied effect of burnishing speed, feed, and number of passes on aluminium specimen. The results were:

- Speed: As the speed is increased to an optimum value, the surface roughness decreases to a least value. Further increase of speed beyond this optimal value results into increase in the surface roughness value.

- Feed: As the feed rate reaches the optimal value, the surface roughness decreases to the least value. Further rise in feed rate beyond this optimal value causes increase in the surface roughness value.

- No. of passes: As the number of passes is increased, the surface roughness value decreases.[14]

15) J. N. Malleswara Rao, Dr. A. Chenna Kesava Reddy, Dr. P. V. Rama Rao (2011) studied the impact of roller burnishing on surface hardness and surface roughness on MS specimen. The conclusions drawn were:

- Burnishing force: It is determined that surface hardness is increased with increase in burnishing force. With further increase in force, surface hardness decreases.
No of passes: It is observed that reduction in surface roughness is highest in earlier five passes. After five passes, there is not much improvement in the surface finish. [15]

16) S. Thamizhmnaii, B. Bin Omar, S. Saparudin, S. Hasan (2008) experimented on Titanium Alloy (Ti-6Al$4 \mathrm{~V}$ ) using a multi roller burnishing tool. The effect of various parameters was:

- Speed: As speed increases, surface roughness decreases while micro hardness increases.

- Feed: As feed rate increases, surface roughness decreases after a considerable increase and micro hardness also increases.

- Depth of Penetration: As DOP increases, the surface micro hardness improves \& surface roughness improves.[16]

17) S. Thamizhmanii, B. Saparudin, S. Hasan (2007) carried out a study of multi-roller burnishing on nonferrous metals (Aluminium, Brass and Copper). The results determined were:

- The surface roughness is increased as the spindle speed, feed and depth of penetration is increased for aluminium, brass and copper.

- The micro hardness also increased along with increase in burnishing speed, feed and depth of penetration for all the three non-ferrous metals.[17]

18) Yatin Patel, Prof. Kiran Patel presented a Review on Various Methods for Process Parameters Optimization of Burnishing Process and TAGUCHI's Approach for Optimization. They concluded that Taguchi's approach is flexible tool for process design optimization.

Taguchi approach includes tools such as orthogonal array, signal to noise ratio, factor impact analysis (ANOVA) is most effective to obtain the contribution of every parameter and to see important parameters that have an effect on the performance characteristic respectively.[18]

\section{CONCLUSION}

From the literature review, it is concluded that there is a wide relevance of process parameters within the field of roller burnishing process that improves quality of bored or turned metal surface and additionally improves the standard of surface roughness and surface hardness.

It can be seen that depth of penetration has highest contribution in improvement of surface roughness. The second main contributor is the number of passes of burnishing tool on the work piece. Speed and feed rate are the least contributors in this process. This method may be effectively utilized in several fields like vehicles producing sector, Production of Machine tools, aerospace Industries, etc. 
IARJSET

International Advanced Research Journal in Science, Engineering and Technology

National Conference on Design, Manufacturing, Energy \& Thermal Engineering (NCDMETE-2017) AGTI's Dr. Daulatrao Aher College Engineering, Vidyanagar Extension, Karad

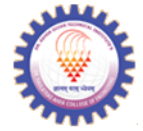

Vol. 4, Special Issue 1, January 2017

\section{FUTURE SCOPE}

1) The study on effect of process parameters like speed, feed, etc on power consumption.

2) Analysis of physical and mechanical properties developed during and after burnishing can be studied by upgrading the FEA model using software like ANSYS to consider the changes.

3) Study the effect on surface hardness by change in process parameters.

4) Study the effect on surface roughness by change in process parameters.

\section{REFERENCES}

[1] Kiran A Patel, Pragnesh K. Brahmbhatt (2016), A comparative study of the RSM and ANN models for predicting surface roughness in roller burnishing, 3rd International Conference on Innovations in Automation and Mechatronics Engineering, ICIAME 2016, 391 - 397

[2] Ashish Deshmukh, Prof. Dr. R. N. Patil (2015), Analyasis and Optimization of Roller Burnishing Process on Cylindrical Surface micro Hardness of Aluminium Alloy, International Journal of Innovative Research in Science, Engineering and Technology, Vol. 4, Issue 7, 6044-6055

[3] Mr. N. M. Qureshi, Mr. Vaibhav B. Patil, Mr. Basavaraj D. Teli, Miss. Radhika S. Mohite and Miss. Sonal S. Patil (2015), Analysis of Effect of Ball and Roller Burnishing Processes on Surface Roughness on EN8 Steel, International Journal of Engineering Research \& Technology (IJERT), Vol. 4 Issue 06, 311-315

[4] Mr. Ashwin Joshi, Dr.R.N.Patil (2015), Optimisation Of Roller Burnishing Process Parameter On Cylendrical Surface On Aluminium Work Pieces, International Journal Of Engineering Sciences \& Research Technology, ISSN: 2277-9655, 638-647

[5] Sundararajan P. N, Nagarajan N. (2015), Study Of Internal Roller Burnishing Operation On En8 Material, International Journal of Research and Innovation in Engineering Technology, Volume: 01 Issue: $12,10-12$

[6] Jayakrishnan J, Suraj R. (2014), Effect Of Roller Burnishing Process On Tool Steel Material Using CNC Lathe, International Journal Of Design And Manufacturing Technology (IJDMT), Volume 5, Issue 3, 155-159

[7] Tao Zhang, Nilo Bugtai, Ioan D. Marinescu (2014), Burnishing of aerospace alloy: A theoretical-experimental approach, Journal of Manufacturing Systems 37 (2015), 472-478

[8] Anish P. Borkar, Prasad S. Kamble and Chandrakant Y. Seemikeri (2014), Surface Integrity Enhancement of Inconel 718 by using Roller Burnishing process, International Journal of Current Engineering and Technology, Vol.4, No.4, 2595-2598

[9] Shashi Prakash Dwivedi, Satpal Sharma, Raghvendra Kumar Mishra (2014), Effects of roller burnishing process parameters on surface roughness of $\mathrm{A} 356 / 5 \% \mathrm{SiC}$ composite using response surface methodology, Springer Adv. Manuf. (2014) 2, 303-317

[10] Jignesh R. Patel, Prof. S. M. Patel (2014), Effect of Process Parameters on Surface Roughness and Surface Hardness in Roller Burnishing Process, International Journal of Science and Research (IJSR), Volume 3 Issue 5, 507-511

[11] Dinesh Kumar, Alok Kumar (2014), Improving Surface Finish and Hardness for M.S. Cylinder using Roller Burnishing, International Journal of Scientific Research Engineering \& Technology (IJSRET), Volume 3 Issue 1, 47-51

[12] K Saraswathamma, G Venkateswarlu, S Venkatarami Reddy (2014), Optimization of surface roughness in the Roller burnishing process using response surface methodology and desirability function, International conference on Emerging Trends in Mechanical Engineering, VOLUME 1, 1-8

[13] P. S. Kamble, V. S. Jadhav (2012), Experimental study of Roller burnishing process on plain carrier of planetary type gear box,
International Journal of Modern Engineering Research (IJMER), Vol.2, Issue.5, 3379-3383

[14] J.N. Malleswara Rao, Dr. A. Chenna Kesava Reddy, Dr. P. V. Rama Rao (2011), Study Of Roller Burnishing Process On Aluminium Work Pieces Using Design Of Experiments, International Journal of Mechanical Engineering and Technology (IJMET), Volume 2, 22-35

[15] J.N. Malleswara Rao, Dr. A. Chenna Kesava Reddy, Dr. P. V. Rama Rao (2011), The effect of roller burnishing on surface hardness and surface roughness on mild steel specimens, INTERNATIONAL JOURNAL OF APPLIED ENGINEERING RESEARCH, DINDIGUL, Volume 1, No 4, 777-785

[16] S. Thamizhmnaii, B. Bin Omar, S. Saparudin, S. Hasan (2008), Surface roughness investigation and hardness by burnishing on titanium alloy, Journal of Achievements in Materials and Manufacturing Engineering, VOLUME 28 ISSUE 2, 139-142

[17] S. Thamizhmanii, B. Saparudin, S. Hasan (2007), A study of multiroller burnishing on non-ferrous metals, Journal of Achievements in Materials and Manufacturing Engineering, VOLUME 22 ISSUE 2, 95-98

[18] Yatin Patel, Prof. Kiran Patel, A Review on Various Approach for Process Parameter Optimization of Burnishing Process and TAGUCHI Approach for Optimization, IJSRD - International Journal for Scientific Research \& Development, Vol. 1, Issue 9, 1818-1820 